\title{
Serum evaluation of leptin, IL-6, IGF-1 and estrogen in obese bitches with early stages of mammary carcinoma
}

\author{
[Avaliação sérica de leptina, IL-6, IGF-1 e estrógeno em cadelas com excesso de peso e \\ portadoras de carcinomas mamários em estágio inicial] \\ S.V. Teixeira, I.L.D. Silva, F.C. Nunes, C.B. Campos, M.R. Oliveira, \\ G.E. Lavalle, G.D. Cassali*
}

Instituto de Ciências Biológicas - Universidade Federal de Minas Gerais -ICB-UFMG - Belo Horizonte, MG

\begin{abstract}
The aim of this study was to relate the serum concentration IL-6, IGF-1, leptin and estrogen in non-castrated bitches with or without overweight and early stage mammary carcinomas. Forty-three bitches were divided into four groups, two groups without mammary carcinomas with and without overweight, and two groups with mammary carcinomas with and without overweight. Overweight bitches, with or without mammary carcinomas, were statistically different from bitches by ideal weight, in relation to ECC, IMCC and body fat percentages $(\mathrm{P}<0.0001)$. There was a positive correlation between ECC and IMCC $(\mathrm{P}<0.0001), \mathrm{ECC}$ and \% GC $(\mathrm{P}<0.0001)$, and IMCC and \% GC $(\mathrm{P}<0.0001)$. A positive correlation was found between serum leptin and IL-6 $(\mathrm{P}=0.0451)$ and leptin and IGF-1 $(\mathrm{P}=0.05)$. A positive correlation $(\mathrm{P}=0.0053)$ between ECC and leptin was found in the analysis of body evaluation methods and serum concentrations, and a negative correlation between ECC and IL-6 $(\mathrm{P}=0.0435)$. Among the fat percentage and the leptin concentration, there was a positive correlation $(\mathrm{P}=0.0016)$, as found between the IMCC and leptin $(\mathrm{P}=0,0209)$. In this study, no association was observed between excessive weight and the presence of early stage mammary carcinomas.
\end{abstract}

Keywords: bitches, obesity, overweight, mammary carcinomas, stage

\section{RESUMO}

Este estudo teve por objetivo relacionar a concentração sérica de IL-6, IGF-1, leptina e estrógeno, em cadelas não castradas com ou sem excesso de peso, e carcinomas mamários em estágio inicial. Quarenta e três cadelas foram divididas em quatro grupos, sendo dois de cadelas sem carcinomas mamários, com e sem excesso de peso, e dois de cadelas com carcinomas mamários, com e sem excesso de peso. Cadelas com excesso de peso, com ou sem carcinomas mamários, foram estatisticamente diferentes de cadelas em peso ideal, em relação às avaliações corporais de ECC, IMCC e percentual de gordura corpórea $(P<0,0001)$. Foi observada uma correlação positiva entre ECC e IMCC ( $P<0,0001)$, ECC e \%GC ( $P<0,0001)$, e IMCC e \%GC (P<0,0001). As análises de estrógeno, leptina, IL-6 e IGF-1 não apresentaram diferenças estatísticas entre os grupos. Demonstrou-se correlação positiva entre as concentrações séricas de leptina e IL-6 $(P=0,0451)$ e leptina e IGF-1 $(P=0,05)$. Encontrou-se correlação positiva entre ECC e leptina $(P=0,0053)$ e negativa entre ECC e IL$6(P=0,0435)$. Entre o percentual de gordura e leptina encontrou-se correlação positiva $(P=0,0016)$, assim como entre IMCC e leptina $(P=0,0209)$. Neste estudo, não se observou associação entre excesso de peso e a presença de carcinomas mamários em estadio inicial.

Palavras-chave: cadela, obesidade, sobrepeso, carcinoma, glândula mamária, estadio

\section{INTRODUCTION}

Mammary tumors are the most frequent neoplasia in bitches (Merlo, 2008; Cassali et al., 2014). Approximately $84 \%$ are diagnosed as malignant, and around $98 \%$ are identified as carcinomas (Nunes et al., 2014). They are more prevalent in middle-aged to older bitches, those not castrated or castrated later in life and there is not a breed predisposition (Sorenmo et al., 2013).

Recebido em 12 de setembro de 2017

Aceito em 5 de março de 2018

*Autor para correspondência (corresponding author)

E-mail: cassalig@icb.ufmg.br 
Obesity is characterized as excessive storage of corporal fat, which is capable of compromising organism homeostasis (Burkholder and Toll, 2000). It is considered a chronic and multifactorial disease, encompassing genetic, biochemical and nutritional aspects (German et al., 2009). Its increase has been observed, both in humans and canines, with the latter incidence varying between $22 \%$ to $40 \%$ (McGreevy et al., 2005; Lund et al., 2006).

Other than its energetic reserve function, adipose tissue is also an endocrine organ that controls the amount of food consumed (Burkholder and Toll, 2000). Obesity is responsible for altering the release of various substances produced by adipocytes, such as leptin, adiponectin, tumor necrosis factor (TNF), interleukin 6 (IL-6), chemokines, hemostatic and hemodynamic factors, as well as neurotrophins (German et al., 2010).

Obesity is considered an independent risk factor for the development of mammary tumors in bitches (Perez Alenza et al., 1998). Previous works correlated obesity with the development of tumors on colon, thyroid, urinary system, endometrium, esophagus and mammary gland in humans (Pergola, Silvestris., 2013; Howe et al., 2013). Cleary et al.

(2010) described the relation between obesity and mammary cancer in murine models. However, there is a lack of studies that associate excessive weight and breast cancer in animals. The objective of this study is to evaluate the relation between obesity, pro-inflammatory cytokines, and serum levels of estrogen in initial staged canine mammary carcinomas.

\section{MATERIALS AND METHODS}

The present study evaluated bitches seen at the Veterinary Hospital from the Federal University of Minas Gerais (UFMG) and originated from the shelter "Centro de Instrução e Adaptação da Aeronáutica (CIAAR)" to compose the control group. The use of animals and procedures for this prospective study was approved by the Ethics Committee on the Use of Animals (protocol 110/2015). In total, forty-three bitches were evaluated, divided in four groups: ten bitches in ideal weight (control), ten obese (without mammary neoplasia), thirteen obese bitches and ten with ideal weight, both of those with malignant mammary neoplasia.

Bitches diagnosed with infectious or endocrine comorbidities, or edema and ascites were excluded from the study, to avoid any influence in seric concentrations or corporal evaluation, respectively. Only non-castrated bitches were used to guarantee the most accurate evaluation of seric estrogen.

The staging was accomplished according with a modified version of the TNM original system established by WHO. This version considers the size of the primary tumor $(\mathrm{T} 1: 0-3 \mathrm{~cm}, \mathrm{~T} 2: 3-$ $5 \mathrm{~cm}, \mathrm{~T} 3:>5 \mathrm{~cm})$, involvement of regional lymph nodes (N0: non-metastatic, N1: metastatic) and presence of distant metastases (M0: absence, M1: presence). Through this system, it was possible to categorize the animals in five stages, as shown in Table 1 (Owen, 1980, Sorenmo et al., 2013). Furthermore, the animals were classified between initial clinical stage (I-III) and advanced (IV-V). All animals present in this study were classified as initial stage.

Table 1. Mean values, standard deviation and " $p$ " concentration of leptin, IL-6, IGF-1 and estrogen in each group

\begin{tabular}{cccccccccc}
\hline & \multicolumn{2}{c}{ Grupo 1 } & \multicolumn{2}{c}{ Grupo 2 } & \multicolumn{2}{c}{ Grupo 3 } & \multicolumn{2}{c}{ Grupo 4 } & \multirow{2}{*}{ P } \\
& M & DP & M & DP & M & DP & M & DP & \\
\hline $\begin{array}{c}\text { Leptina } \\
(\mathrm{ng} / \mathrm{mL})\end{array}$ & 9.5301 & 7.695 & 8.8883 & 8.61 & 10.0861 & 6.312 & 6.48 & 5.15 & 0.73 \\
IL-6 $(\mathrm{pg} / \mathrm{mL})$ & 0.9059 & 0.622 & 1.01007 & 0.36 & 0.6001 & 0.485 & 0.648 & 0.48 & 0.242 \\
IGF-1 $(\mathrm{ng} / \mathrm{mL})$ & 274.096 & 127.72 & 203.0201 & 113.79 & 267.934 & 139.3 & 263.017 & 193.6 & 0.447 \\
E2 $(\mathrm{pg} / \mathrm{mL})$ & 832.557 & 246.02 & 644.789 & 254.77 & 604.526 & 203.2 & 683.65 & 313.4 & 0.12 \\
\hline
\end{tabular}

Three different evaluations of corporal condition were done. The corporal score was obtained by the Body Condition Scoring System. This system varies between 1 and 9, being escore 01 , cachectic, and score 09, animal morbidly obese (Laflamme, 1997). The canine body mass index, 
an adaptation of the human body mass index, was calculated from the weight $(\mathrm{kg}) /$ (height in meters $)^{2}$, being the height measure from the atlanto-occipital joint to the ground, right behind the hind limbs. Due to the great variation on size in dogs, two correction factors were proposed: in large or giant breed dogs decreases $20 \%$ of the value, and in miniature breeds, meaning less than 10 kilograms, increases the value in $10 \%$. The animals were divided in: underweight $(>11.7 \mathrm{~kg})$, ideal weight (between 11.8 and $15 \mathrm{~kg}$ ), overweight between 15 and $18.6 \mathrm{~kg}$ and obese over $18.7 \mathrm{~kg}$ (Muller and Schossler, 2008). The percentage of corporal fat $(\% \mathrm{CF})$ was calculated from the relation between the pelvic circumference and the length of the right hind limb - from the calcaneus tuberosity until the middle of the patellar ligament $(\mathrm{CP}$ and $\mathrm{CR}$ respectively) using the formula $\% \mathrm{CF}=$ $1,7(\mathrm{CRcm})+0,93(\mathrm{CPcm})+5$. The bitches were classified in: caiquetic $(<5)$, thin $(5$ to 15$)$, ideal weight (16 to 25$)$, overweight (26 to 35$)$ and morbidly obese (>35) (Burkholder and Toll, 2000).

The surgical excision of mammary neoplasias in the bitches from this study were performed at Veterinary Hospital, UFMG. The collected neoplasms were sent to the laboratory of compared pathology, at Instituto de Ciências Biológicas UFMG, for histopathologic diagnosis. The tumors were fixed in neutral buffered formalin (10\%) and prepared for inclusion in paraffin. Histological sections of $4 \mu \mathrm{m}$ were obtained and stained with Hematoxylin-Eosin. The determination of the histological type of the tumor was performed according the classification proposed by the Consensus for the Diagnosis, Prognosis and Treatment of Canine Mammary Tumors (Cassali et al., 2014).

To perform the serum test, $3 \mathrm{~mL}$ samples of blood from each animal were collect, by venous puncture, in anticoagulant tubes (VacuTainer $\left.{ }^{\circledR}\right)$. The samples were centrifuged for five minutes at 3000RPM to separate the serum and the cells concentrated. Once centrifuged, the serum was aliquoted and stored in criotubes inside a freezer $-80^{\circ} \mathrm{C}$.

Enzyme-Linked Immunosorbent Assay (ELISA) was used to perform the seric evaluation of estrogen, leptin, IGF-1 and IL-6, being the first two evaluated by competitive ELISA, and the last two sandwich ELISA. The samples were processed in duplicate, and in each run a positive control serum, a negative control and a white serum were added.

The data was analyzed using the Student T-test, and two way ANOVA followed by the post-test de Dums, as appropriated. The correlations were evaluated by the Spearman or Pearson test. The statistical analyses were performed by the program GraphPad Prism (GraphPad Software, San Diego, CA) 5.0 version. Values were only considered significant when $\mathrm{P}<0.05$.

\section{RESULTS}

Forty-three bitches were evaluated, where $38.64 \%$ didn't have defined breed and 61.36\% were purebred with Labrador $10 \%$ and Poodle $10 \%$ the most common breeds. Of these, $40.92 \%$ were considered large-breeds, $22.72 \%$ mediumand $36.36 \%$ small-breed. Obese and ideal weight bitches presented mean age of $7.47 \pm 2.83$ and $7.7+3.09$, respectively. The most frequent histopathologic diagnosis of mammary neoplasias was the mixed tumor carcinoma $70 \%$, followed by the papillary carcinoma $12.04 \%$, tubular carcinoma $4.34 \%$, apocrine carcinoma $4.34 \%$ and adenoma with in situ carcinomatous areas of solid pattern $4.34 \%$.

The evaluation of ECC, IMCC and percentage of body fat demonstrated differences between the groups studied $(\mathrm{P}<0.0001)$, where the obese bitches, with or without mammary carcinomas, presented significant statistical differences from the ideal weight bitches (Figure 1).

A strong positive correlation between ECC and IMCC $(r=0.8686 ; \mathrm{P}<0.0001), \mathrm{ECC}$ and \%CF $(\mathrm{r}=0.8808 ; \mathrm{P}<0.0001), \mathrm{IMCC}$ and $\% \mathrm{CF}(\mathrm{r}=$ $0.7449 ; \mathrm{P}<0.0001$ ) was observed (Figure 2).

The estrogen, leptin, IL-6 and IGF-1 analysis did not reveal significant statistical difference between the studied groups (Table 1). A positive correlation was demonstrated between the seric concentration of leptin and IL-6 $(r=0.3072$; $\mathrm{P}=$ 0.0451 ) and between leptin and IGF-1 ( $\mathrm{r}=$ 0.2998; $\mathrm{P}=0.05$ ) (Table 2). 

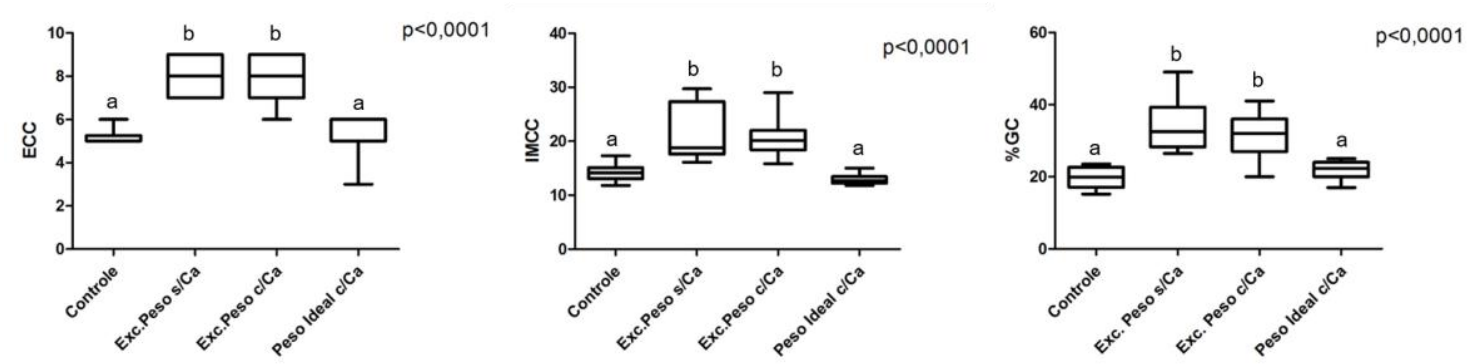

Figure 1. Canine Corporal Score, Canine body mass index and \% of Corporal fat from control bitches without $\mathrm{Ca}$, obese without $\mathrm{Ca}$, obese with $\mathrm{Ca}$ and ideal weight with $\mathrm{Ca}$. (Ca: mammary carcinoma).
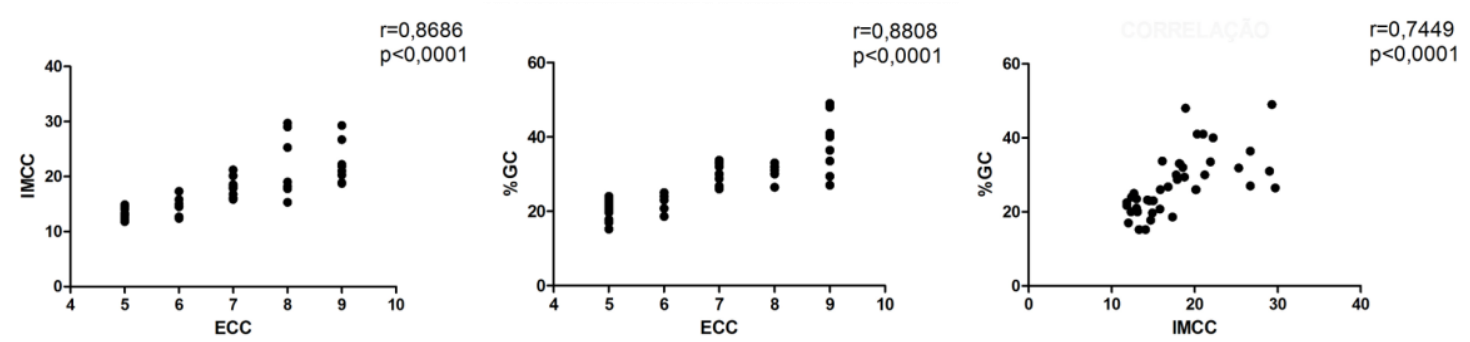

Figure 2. Positive correlation between ECC, IMCC, \%CF.

Table 2. Positive correlation between seric concentration of leptin, IL-6, IGF-1 and Estrogen (E2)

\begin{tabular}{lcccc} 
& Leptina & IL-6 & IGF-1 & Estrógeno \\
\hline Leptina & 1 & $\mathrm{r}=0.3072 \mathrm{P}=0.0451^{*}$ & $\mathrm{r}=0.2998 \mathrm{P}=0.0508^{*}$ & $\mathrm{r}=0.055 \mathrm{P}=0.7678$ \\
IL-6 & $\mathrm{r}=0.3072 \mathrm{P}=0.0451^{*}$ & 1 & $\mathrm{r}=-0.014 \mathrm{P}=0.2960$ & $\mathrm{r}=0.3276 \mathrm{P}=0.0888$ \\
IGF-1 & $\mathrm{r}=0.2998 \mathrm{P}=0.0508^{*}$ & $\mathrm{r}=-0.014 \mathrm{P}=0.2960$ & 1 & $\mathrm{r}=-0.1 \mathrm{P}=0.5339$ \\
E2 & $\mathrm{r}=0.055 \mathrm{P}=0.7678$ & $\mathrm{r}=0.3276 \mathrm{P}=0.0888$ & $\mathrm{r}=-0.1 \mathrm{P}=0.5339$ & 1 \\
\hline
\end{tabular}

When analyzing the corporal evaluation methods and the seric concentrations, a positive correlation was found $(\mathrm{r}=0.4493 ; \mathrm{P}=0.0053)$ between ECC and leptin, and between ECC and

\section{DISCUSSION}

The mean age for overweight bitches was $7.4 \pm 2.89$ years-of-age, evidencing that older animal are more predisposed to weight gain. At older age, there is descent in lean body mass, which also causes a decrease on basal metabolism, daily energy requirement and voluntary activity (Diez \& Nguyen, 2006).

However, there are variables capable of influencing weight gain and increase in fat storage, such as diet, exercise and, including, owner profile and environment.
IL-6 was observed a negative correlation ( $\mathrm{r}=$ $0.3591 ; \mathrm{P}=0.0435$ ). A positive correlation was found between fat percentage and leptin concentration $(r=0.3785 ; \mathrm{P}=0.0209)$.

The mean age for bitches with mammary carcinoma is $9.0 \pm 1.95$ years-of-age and $10.1 \pm 2.33$ on obese and ideal weight groups, respectively, confirming the mean age, between 6 and 12 years, for the increase of mammary neoplasias, especially malignant ones (Cassali $e t$ al., 2014). Obese bitches developed mammary carcinomas earlier than the ideal body condition group, demonstrating a possible influence of being overweight in the development in mammary neoplasias. Perez Alenza et al. (1998) described that obese bitches, since youth or until one year before the tumor diagnosis, can increase the risk of breast cancer. 
Obesity is the most common current nutritional variation in small animals Being overweight is the nutritional variation most common in small animals nowadays (McGreevy et al., 2005). Diez \& Nguyen (2006) reported a prevalence of at least $20 \%$ overweight dogs in industrialized countries and in big cities. As in humans (Romacho et al., 2014), obesity is associated with a range of diseases and physiological changes in companion animals, especially in dogs (Zoran, 2010). The association with mammary neoplasias has being studied due to the importance of both diseases and their possible combination.

Obesity is one of the most subjective clinicpathologic conditions to be diagnosed, and diagnosis is performed mainly through physical examination. The correct body composition assessment, using objective measurements, allows identification of risk stages, quantification of excess body weight and definition of an ideal weight (Burkholder and Toll, 2000; Muller et al., 2008). The results found in this work demonstrated the importance of associating different diagnostic methods for overweight and obesity. They are complementary, and more than one measure helps to correctly diagnose the animal's body condition. The ECC, established by Laflamme (1997), is the most subjective, albeit simplest and fastest, and it is possible to perform it during the clinical examination. The IMCC and the morphometric measures cannot be considered complexes and, to determine fat percentage, it is necessary to use the values found in a mathematical formula (Burkholder and Toll, 2000; Muller and Schossler 2008). Associated, these three methods are capable of determining, with precision, the animal body condition.

The exact mechanism by which obesity influences cancer development and prognosis remains unknown, although factors secreted by adipocytes, including aromatase, leptin (Guo et al., 2012), adiponectin, IGF-1 (Dolka et al., 2011) and inflammatory cytokines (IL-6, TNF$\alpha$ ), were described as important Lim et al., 2015).

Obesity is described as a disease capable of influencing the mammary cancer development, progression and prognostic in women postmenopausal (Pergola and Silvestris, 2013;
Howe et al., 2013) as in bitches (Perez-Alenza et al., 1998; Dolka et al., 2011; Lim et al., 2015). The absence of statistical difference in the serum concentrations of leptin, IL-6, IGF-1 and estrogen between the analyzed groups may be due the population of this study being composed of bitches diagnosed with mammary carcinoma at initial stage. The inflammation, in some tissues, can, commonly, increase the chances of cancer. Cytokines and chemokines are components capable of promoting angiogenesis, metastasis, immune system evasion and response to chemotherapy agents (Germano et al., 2008). Some authors described that cytokines influenced by obesity were responsible for increasing cancer risk (Pérez Alenza et al., 1998; German et al., 2010; Cleary et al., 2010). They also have shown that these inflammatory factors contribute to tumor progression and higher mortality rate due the tumor (Simpson and Brown, 2013). Higher concentrations of inflammatory factors have been associated to worse prognosis factors, such as advanced stage (Martins et al., 2016). One example would be the high IL-6 concentration, due the caused oxidative stress, leading to the tumor progression and promotion (Madeddu et al., 2015).

The absence of significant differences between the IGF-1 concentrations contradicts the findings of Greer et al. (2011), who observed higher concentration in overweight bitches. According to Nam et al. (1997) and Goodwin et al. (2002) the higher IGF-1 serum concentration is associated with insulin increase.

Queiroga et al. (2010) described that overweight or obese animals with mammary neoplasia presented higher serum concentration of IGF-1 when compared with bitches without neoplasias. However, the same results were not found in this study, possibly because IGF-1 is involved in angiogenesis stimulation and, mainly, progression of neoplasia (Chong et al., 2007). Previous studies demonstrated that mice deficient in IGF-1 were not only smaller, but also lived longer and presented a considerable reduction on diseases related to aging as cataracts, atherosclerosis and cancer (Menezes Oliveira et al., 2006; Shechter et al., 2007).

The lack of statistical relevance in serum concentration of IL-6 among the different groups can be explained by the fact that the increase in these concentrations is more related to mammary 
neoplasias of high grade and advanced staging (Balaban et al., 2015; Martins, 2016). This result might be due to the serum concentration of IL- 6 being influenced by several factors such as age, where older animals can undergo chronic inflammatory processes without evident clinical signs, altering their cytokines pattern.

The positive correlation between ECC and leptin reiterates the leptin importance as a marker of adiposity in dogs (Ishioka et al., 2006; Kil et al., 2010), being possible its utilization on the clinical routine to obesity diagnosis. The negative correlation between ECC and IL-6 is contrary to the association between overweight and inflammation, mainly subacute, described in previous studies (Garofalo and Swanson, 2006; Kim et al., 2009; German et al., 2010; Ghosh and Ashcraf, 2013; Gilbert and Slingerland, 2013; Ramos-Nino, 2013; Vansaun, 2013; Bastien et al., 2016; Martins et al., 2016). One hypothesis is there is a threshold for the increase of this interleukin, once the IL- 6 concentration was discreetly higher in overweight bitches comparing to obese, with no statistical relevance.

The correlations observed between serum concentrations of leptin and IL-6, such as between leptin and IGF-1, without difference between bitches with or without mammary neoplasia, demonstrated the low degree chronic inflammation that overweight or obese animals commonly develop (German et al., 2010; Van de Velde et al., 2012; Bastien et al., 2016). Leptin and IL-6 are related to carcinogenic activities, involved in tumoral initiation and progression (Garofalo and Surmacz, 2006; Ghosh and Ashcraft, 2013; Gilbert and Slingerland, 2013; Vansaun, 2013; Bastien et al., 2016; Martins et al., 2016), being expected to find higher levels of these cytokines in bitches with mammary neoplasias.

Estrogen is a sexual hormone, associated with the central accumulation of adipocytes. In menopausal women, the adipose tissue is an important source of estrogen and it is considered the principal motor for the cell development in mammary tumors (Brown, 2014). Considering the role, already well defined, of estrogen in canine mammary carcinogenesis (Schneider et al., 1969; Silva et al., 2004; Bocardo, 2008) an increase in estrogen serum concentration in overweight bitches with mammary neoplasia was expected, however, it was not demonstrated. This difference, possibly, was not found because the bitches used in this study had different phases in the estrous cycle.

\section{CONCLUSION}

Increased fat percentage and overweight were directly related to serum leptin levels. There was no difference in concentrations of IL-6, IGF-1 and estrogen in bitches with overweight with or without mammary carcinoma at initial stage.

\section{REFERENCES}

BALABAN, S.; LEE, L.S.; SCHREUDER, M. et al. Obesity and cancer progression: is there a role of fatty acid metabolism? Biomed. Res. Int., v.2015, p.274-585, 2015.

BASTIEN, B.C.; PATIL, A.; SATYARAJ, E. Veterinary immunology and immunopathology. The impact of weight loss on circulating cytokines in Beagle dogs. Vet. Immunol. Immunopathol., v.163, p.174-182, 2016.

BOCARDO, M.; DABUS, D.M.M.; TENTRIN, T.C. et al. Influência hormonal na carcinogênese mamária em cadelas. Rev. Cient. Eletrôn. Med. Vet., v.6, p.1-6, 2008.

BROWN, K. A. Impact of obesity on mammary gland inflammation and local estrogen production. Journal of mammary gland biology and neoplasia, v. 19, n. 2, p. 183-9, 2014.

BURKHOLDER, W.J.; TOLL, P.W. Obesidad. In: HAND, M.S. et al. Nutrición clinica en pequeños animales. 4.ed. 2000. p.475-508.

CASSALI, G.D.; LAVALLE, G.E.; FERREIRA, E. et al. Consensus for the diagnosis, prognosis and treatment of canine mammary tumors - 2013. Braz. J. Vet. Pathol., v.7, p.38-69, 2014.

CLEARY, M.P.; GROSSMANN, M.E.; RAY, A. Effect of obesity on breast cancer development. Vet. Pathol., v.47, p.202-2013, 2010.

CHONG, Y.M. et al. The potential clinical applications of insulin-like growth factor-1 ligand in human breast cancer. Anticancer Research., v.27, p.1617-1624, 2007.

DIEZ, M.; NGUYEN, P. Obesity: epidemiology, pathophysiology and management of the obese dog. In: PIBOT, P. et al. Encyclopedia of canine clinical nutrition. Airmargues: Diffo Print, 2006. p.2-57. 
DOLKA, I.; MOTYL, T.; MALICKA, R. et al. Relationship between receptors for insulin-like growth factor - I, steroid hormones and apoptosis-associated proteins in canine mammary tumors. Pol. J. Vet. Sci., v.14, p.245251,2011

GAROFALO, C.; SURMACZ, E. Leptin and cancer. J. Cell Physiol., v.207, p.12-22, 2006.

GERMAN, A.J.; HERVERA, M.; HUNTER, L. et al. Improvement in insulin resistance and reduction in plasma inflammatory adipokines after weight loss in obese dogs. Domest. Anim. Endocrinol., v.27, p.214-226, 2009.

GERMAN, A.J.; RYAN, V.H.; GERMAN, A.C. et al. Obesity, its associated disorders and the role of inflammatory adipokines in companion animals. Vet. J., v.185, p.4-9, 2010.

GERMANO, G.; ALLAVENA, P.; MANTOVANI, A. Cytokines as a key component of cancer-related inflammation. Cytokine, v.43, p.374-379, 2008.

GHOSH, S.; ASHCRAFT, K. An IL-6 link between obesity and cancer. Front Biosci., v.5, p.461-478, 2013.

GILBERT, C.A.; SLINGERLAND, J.M. Cytokines, obesity, and cancer: new insights on mechanisms linking obesity to cancer risk and progression. Аnnu. Rev. Med., v.64, p.45-57, 2013.

GOODWIN, P.J.; ENNIS, M.; PRITCHARD, K.I. et al. Fasting insulin and outcome in earlystage breast cancer: results of a prospective cohort study. J. Clin. Oncol., v.20, p.42-51, 2002.

GREER, K.A.; HUGHES, L.M.; MASTERNAK, M.M. Connecting serum IGF-1, body size, and age in the domestic dog. Age (Dordr.), v.33, p.475-483, 2011.

GUO, S.; LIU, M.; WANG, G. et al. Oncogenic role and therapeutic target of leptin signaling in breast cancer and cancer stem cells. Biochim. Biophys. Acta, v.1825, p.207-222, 2012.

HOWE, L.R.; SUBBARAMAIAH, K.; HUDIS, C.A. et al. Molecular pathways: Adipose inflammation as a mediator of obesity-associated cancer. Clin. Cancer Res., v.19, p.6074-6083, 2013.
ISHIOKA, K.; HOSOYA, K.; KITAGAWA, H. et al. Plasma leptin concentration in dogs: effects of body condition score, age, gener and breeds. Res. Vet. Sci., v.82, p.11-15, 2006.

KIL, D.Y.; SWANSON, K.S. Endocrinology of Obesity. Vet. Clin. N. Am. Small Anim. Pract., v.40, p.205-219, 2010.

KIM, J.H.; BACHMANN, R.A.; CHEN, J. Interleukin-6 and insulin resistance. Vitam. Horm., v.80, p.613-633, 2009.

LAFLAMME, D. Development and validation of a body condition score system for dogs. Canine Pract., v.22, p.10-15, 1997.

LIM, H.Y.; IM, K.S.; KIM, N.H. et al. Obesity, expression of adipocytokines, and macrophage infiltration in canine mammary tumors. Vet. J., v.1, p.1-6, 2015.

LUND, E.M.; ARMSTRONG, P.J.; KIRK, C.A. et al. Prevalence and risk factors for obesity in adult dogs from private US veterinary practices. Int. J. Appl. Res. Vet. Med., v.4, p.177-186, 2006.

MADEDDU, C.; GRAMIGNANO, G.; FLORIS, C. et al. Role of inflammation and oxidative stress in post-menopausal estrogen-dependent breast cancer. J. Cell. Mol. Med., v.18, p.25192529, 2014.

MARTINS, G.R.; GELALETI, G.B.; MOSCHETTA, M.G. et al. Proinflammatory and anti-inflammatory cytokines mediated by NF- $\kappa \mathrm{B}$ factor as prognostic markers in mammary tumors. Mediator Inflamm., v.2016, 2016.

McGREEVY, P.D.; THOMSON, P.C.; PRIDE, C. et al. Prevalence of obesity in dogs examined by Australian veterinary practices and the risk factors involved. Vet. Rec., v.156, p.695-702, 2005.

MENEZES OLIVEIRA, J.L.; MARQUESSANTOS, C.; BARRETO-FILHO, J.A. et al. Lack of evidence of premature atherosclerosis in untreated severe isolated growth hormone $(\mathrm{GH})$ deficiency due to a GH-releasing hormone receptor mutation. J. Clin. Endocrinol. Metab., v.91, p.2093-2099, 2006.

MERLO, D.F. Cancer incidence in pet dogs: findings of the animal tumor registry of Genoa, Italy. J. Vet. Intern. Med., v.22, p.976-984, 2008.

MULLER, D.C.M.; SCHOSSLER, J.E.W. Adaptação do índice de massa corporal humano para cães de companhia. Ciênc. Rural, v.38, p.1038-1043, 2008. 
NAM, S.Y.; LEE, E.J.; KIM, K.R. et al. Effect of obesity on total and free insulin-like growth factor (IGF)-1, and their relationship to IGFbinding protein (BP)-1, IGFBP-2, IGFBP-3, insulin, and growth hormone. Int. J. Obesity, v.21, p.355-359, 1997.

NUNES, F.C.; GAMBA, C.O.; DAMASCENO, K.A. et al. Analisis of clinico-pathological data, therapeutical conduct and overall survival of canine mammary lesions attended at veterinary hospital of the Federal Hospital of the Federal University of Minas Gerais (UFMG). Abstracts II Encontro de Patologia Mamária Diagnóstico, Prognóstico e Tratamento das Neoplasias Mamárias da Cadela. Braz. J. Vet. Pathol., v.7, p.106-143, 2014.

OWEN, L.N. The TNM classification of tumors in domestic animals. Geneva: World Health Organization, $1980.53 \mathrm{p}$.

PEREZ ALENZA, M.D.; RUTTEMAN, G.R.; PEÑA, L. et al. Relation between habitual diet and canine mammary tumors in a case-control study. J. Vet. Intern. Med., v.12, p.132-139, 1998.

PERGOLA, G.; SILVESTRIS, F. Review article. Obesity as a major risk factor for cancer. $J$. Obesity, v.2013, 2013.

QUEIROGA, F. L. et al. Serum and intratumoural $\mathrm{GH}$ and IGF-I concentrations: Prognostic factors in the outcome of canine mammary cancer. Research in Veterinary Science, v. 89, n. 3, p. 396-403, 2010.

RAMOS-NINO, M.E. The role of chronic inflammation in obesity-associated cancers. ISRN Oncol., v.2013, p.11-12, 2013.

ROMACHO, T.; ELSEN, M.; ROHRBORN, D.; ECKEL, J. Adipose tissue and its role in organ crosstalk. Acta Physiol., v.210, p,733-53, 2014.
SCHNEIDER, R.; DORN, C.R.; TAYLOR, D. Factors influencing canine mammary cancer development and postsurgical survival. J. Natl. Cancer Inst., v.43, p.1249-1261, 1969.

SHECHTER, M.; GINSBERG, S.; SCHEINOWITZ, M. et al. Obese adults with primary growth hormone resistance (Laron syndrome) have normal endothelial function. Growth Horm. IGF Res., v.17, p.165-170, 2007.

SILVA, A.E.D.A.; SERAKIDES, R.; CASSALI, G.D. Carcinogênese hormonal e neoplasias hormônio-dependentes. Ciênc. Rural, v.34, p.625-633, 2004.

SIMPSON, E.R.; BROWN, K.A. Minireview: obesity and breast cancer: a tale of inflammation and dysregulated metabolism. Mol. Endocrinol., v.27, p.715-725, 2013.

SORENMO, K.U.; DEANNA, R.W.; GOLDSMIDT, R.H. Tumors of the mammary gland. WITHROW SJ., VAIL DM. Withrow \& MacEwen's small animal clinical oncology. 5.ed. Philadelphia: W.B. Saunders Company, 2013. p.553-571.

VAN DE VELDE, H.; JANSSENS, G.P.; STUYVEN, E. et al. Short-term increase of body weight triggers immunological variables in dogs. Vet. Immunol. Immunopathol., v.145, p.431-437, 2012.

VANSAUN, M.N. Molecular pathways: adiponectin and leptin signaling in cancer. Clin. Cancer Res., v.19, p.1926-1932, 2013.

WAUTERS, M.; CONSIDINE, R.V.; VAN GAAL, L.F. Human leptin: from an adipocyte hormone to an endocrine mediator. Eur. J. Endocrinol., v.143, p.293-311, 2000.

ZORAN, D.L. Obesity in dogs and cats: a metabolic and endocrine disorder. Vet. Clin. $N$. Am. Small Anim. Pract., v.40, p.221-23, 2010. 